\title{
PERANCANGAN SISTEM KENDALI SUHU PADA OVEN LISTRIK HEMAT ENERGI DENGAN METODE KONTROL ON-OFF
}

\author{
Ari Purnomoaji*), Abdul Syakur dan Agung Warsito \\ Departemen Teknik Elektro, Universitas Diponegoro \\ Jl. Prof. Sudharto, SH, Kampus UNDIP Tembalang, Semarang 50275, Indonesia \\ ${ }^{*}$ E-mail:aripurnomoaji7 @gmail.com
}

\begin{abstract}
Abstrak
Pada era ini kita membutuhkan peralatan elektronik yang hemat dan efisien, contohnya oven. Dalam oven terdapat elemen pemanas dan sistem pengendalian suhu. Sistem pengendalian suhu yang digunakan harus bekerja sesuai dengan suhu referensi yang ingin dicapai. Oleh karena itu dibutuhkan metode kontrol yang baik untuk mendapatkan hasil yang optimal. Pada Penelitian ini dirancang kendali suhu pada oven listrik dengan menggunakan sensor thermocouple tipe-K dan mikrokontroler Arduino Nano sebagai otak pengendalian utama. Metode kontrol yang digunakan untuk mengendalikan suhu pada oven listrik adalah on-off dengan memanfaatkan relay sebagai aktuator. Pada Penelitian ini menggunakan referensi suhu yaitu $40^{\circ} \mathrm{C}, 60^{\circ} \mathrm{C}$ dan $80^{\circ} \mathrm{C}$. Hasil pengujian metode kontrol on-off terhadap sepuluh pengujian dengan variasi pemanas dan suhu yaitu mampu menghasilkan keluaran suhu sesuai dengan variasi referensi suhu yang diberikan meskipun masih berosilasi.
\end{abstract}

Kata kunci: Sistem kendali suhu, Thermocouple tipe-k, Arduini Nano, metode kontrol on-off

\begin{abstract}
In this era we need efficient electronic equipment, for example ovens. In the oven there is a heating element and a temperature control system. The temperature control system used must work according to the temperature of the reference to be achieved. Therefore, a good control method is needed to get optimal results. In this Final Project, temperature control is designed on an electric oven using a K-type thermocouple sensor and Arduino Nano microcontroller as the main control brain. The control method used to control the temperature in an electric oven is on-off by utilizing a relay as an actuator. In this Final Project uses a reference temperature of $40^{\circ} \mathrm{C}, 60^{\circ} \mathrm{C}$ and $80^{\circ} \mathrm{C}$. The test results of the on-off control method on ten tests with heating and temperature variations are able to produce temperature output in accordance with the given temperature reference variation even though it is still oscillating.
\end{abstract}

Keywords: Temperature control system, Thermocouple type-k, Arduini Nano, on-off control method

\section{Pendahuluan}

Kebutuhan hidup manusia pada saat ini semakin kompleks, sehingga untuk membantu kehidupan sehari-hari diperlukan teknologi yang praktis, murah dan aman. Kemajuan teknologi ini tentunya tidak hanya bertujuan untuk teknologi itu sendiri melainkan yang lebih penting adalah untuk kesejahteraan manusia. Salah satunya pemanfaatannya adalah dalam bidang industri. Pada salah satu industri yaitu proses pemanggangan ikan. Maka diperlukan suatu alat pemanggang (oven) yang bersifat aman, hemat dan ramah lingkungan [1].

Oven adalah alat yang digunakan untuk mengeringkan suatu bahan basah menjadi bahan kering agar dapat disimpan dalam jangka waktu yang lama. Proses pengeringan dengan oven menggunakan media yang dapat menampung suhu panas secara konstan sehingga bisa mendapatkan hasil pembakaran yang sempurna [2].
Sistem pengontrolan temperatur memegang peranan penting untuk mengendalikan suhu pada suatu level yang diinginkan. Sistem kendali atau control system adalah susunan komponen fisika yang dihubungkan sedemikian rupa sehingga membentuk suatu kesatuan utuh yang fungsinya untuk mengatur, memerintah sistem itu sendiri atau sistem lainnya [3]. Untuk itu diperlukan suatu sistem kontrol yang dapat mempertahankan kondisi tersebut. Salah satu metode pengontrolan adalah proses pengendalian on-off.

Proses pengendalian on-off dapat diterapkan pada oven listrik. Kontrol on-off adalah metode kontrol yang sederhana. Pada kontrol on-off, kontroler berfungsi sebagai saklar yang diaktifkan oleh sinyal galat sehingga menghasilkan aksi kontrol diskontinu berupa sinyal step. Sehingga nilai besaran kontrol pada metode control on-off akan berosilasi di sekitar nilai set point [4]. Untuk kontrol 
pemanas, output on bila temperatur dibawah titik set, dan off bila temperatur di atas titik set. Bila oven lebih dingin dari temperatur titik set maka pemanas dikembalikan pada daya maksimum, dan bila oven lebih panas dari temperatur titik set maka pemanas dialihkan ke keadaan off [5].

Penelitian ini dilakukan untuk mendapatkan metode terbaik dalam pemanasan dan hemat energi. Dengan membandingkan respons sistem dengan metode kontrol on-off pada pemanas resistif dan pemanas induksi.

Tujuan dari Penelitian ini adalah menerapkan oven listrik hemat energi dan ramah lingkungan dengan pengontrolan on-off berbasis Arduino Nano. Keluaran dari pengontrolan akan mengatur tegangan yang diberikan kepada kedua pemanas sehingga suhu dari oven listrik dapat dikendalikan.

\section{Metode}

Oven listrik dengan pengontrolan suhu menggunakan metode kontrol on-off dalam Penelitian ini dibagi menjadi sistem elektronik dan perancangan perangkat lunak. Perancangan sistem elektronik meliputi perancangan catu daya, perancangan mikrokontroler Arduino Nano, perancangan sensor suhu MAX 6675, perancangan potensiometer, perancangan $\mathrm{LCD}$, perancangan driver relay dan heater, serta perancangan perangkat lunak. Pada perancangan perangkat lunak meliputi algoritma dan diagram alir oven listrik, dan perancangan program sistem mikrokontroler Arduino Nano.

\subsection{Perancnagan Perangkat Keras}

Perancangan perangkat keras berisikan blok diagram perancangan perangkat keras pengontrolan suhu dengan Arduino Nano. Blok diagram perancangan perangkat keras secara keseluruhan adalah seperti ditunjukkan pada Gambar 1. Perangkat keras dirancang untuk membentuk oven listrik dengan menggunakan metode kontrol on-off.

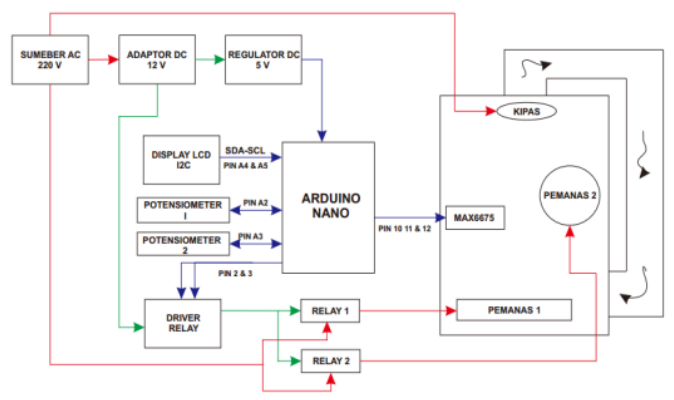

Gambar 1. Blok Diagram Rancangan Perangkat Keras Sistem

Spesifikasi perancangan perangkat keras dari sistem oven listrik ini terdiri dari: a. Oven listrik sebagai plant utama untuk menaruh ikan dan sebagai tempat sirkulasi udara. Didalamnya terdiri dari pemanas 1 dan 2, kipas pemanas, dan sensor MAX667

b. Kipas 1 (heater) sebagai penyebar aliran udara pada ruangan pemanas sehingga panas didalam oven listrik akan merata.

- Daya : 21 Watt

- Tegangan : 220-240 V

- $\quad$ Frekuensi : $50 \mathrm{~Hz}$

- Arus : $0.14 \mathrm{~A}$

c. Mikrokontroler Arduino Nano digunakan sebagai unit kontroler untuk pemrosesan kontrol on-off dan penentu operasi yang dijalankan sistem

d. LCD (liquid crystal display) dan driver I2C LCD berfungsi sebagai media tampilan selama proses pengendalian berlangsung.

e. Sensor MAX6675 adalah sensor pendeteksi suhu ruangan oven, kemudian data suhu dikirim ke mikrokontroler yang akan digunakan sebagai umpan balik dari sistem kendali on-off , kemudian datanya ditampilkan ke LCD.

$f$. Catu daya sebagai sumber daya bagi semua komponen yang digunakan.

g. Potensiometer digunakan sebagai masukan sistem adalah besarnya suhu oven oven listrikyang diinginkan dalam satuan celcius sebagai set point

h. Driver Relay sebagai rangkaian yang berfungsi untuk mengendalikan relay agar panas yang timbul sesuai dengan masukkan.

\subsection{Perancnagan Perangkat Lunak}

Perancangan software pada penelitian ini berisikan algoritma beserta diagram alir keseluruhan dan prosedur program metode kontrol on-off dalam oven listrik. Pada mikrokontroler Arduino Nano dan sensor yang diprogram menggunakan bahasa $\mathrm{C}++$ dengan program Arduino IDE (Integrated Development Environment) pada sistem komunikasi, perangkat komunikasi digunakan sebagai media penghubung antara mikrokontroler ke Interface dengan program arduino.

\subsubsection{Algoritma dan Diagram Alir Oven listrik}

Perancangan dari algoritma dan diagram alir oven listrik digunakan sebagai dasar alur dari sistem yang akan digunakan . algoritma perangkat lunak dari oven listrik adalah sebagai berikut:

1. Mulai.

2. Inisialisai I/O register dan variabel.

3. Deteksi dan inisialisasi sensor MAX6675

4. Tampilan LCD "BISMILLAH PENELITIAN" kemudian "PENGONTROLAN OVEN"

5. Kipas menyala setelah inisialisasi

6. Pambacaan suhu oleh sensor suhu MAX6675

7. Proses penentuan data parameter kontrol setpoint I dengan memutar potensiomter I 
8. Proses penentuan data parameter kontrol setpoint II dengan memutar potensiomter II

9. Tampilan LCD "PEMBACAAN SUHU OVEN", "SP1: (setpoint I)", "SP2: (setpoint II)", "SUHU: (suhu terbaca)",

10. Proses pengukuran suhu

11. Sistem kontrol on-off bekerja

12. Jika suhu terbaca memiliki nilai dibawah nilai setpoint maka sistem kontrol berada pada kondisi $O N$ sehingga relay akan dalam keadan NC

13. Pemanas berkerja memanaskan oven

14. Jika suhu terbaca I maupun II memiliki nilai diatas nilai setpoint maka sistem kontrol berada pada kondisi $O F F$ sehingga relay akan dalam keadan NO

15. Pemanas berhenti memanaskan oven

16. Sistem akan close loop dan kembali pada proses pengukuran suhu

17. Selesai

Diagram alir oven yang ditunjukkan oleh Gambar 2. sebagai berikut:

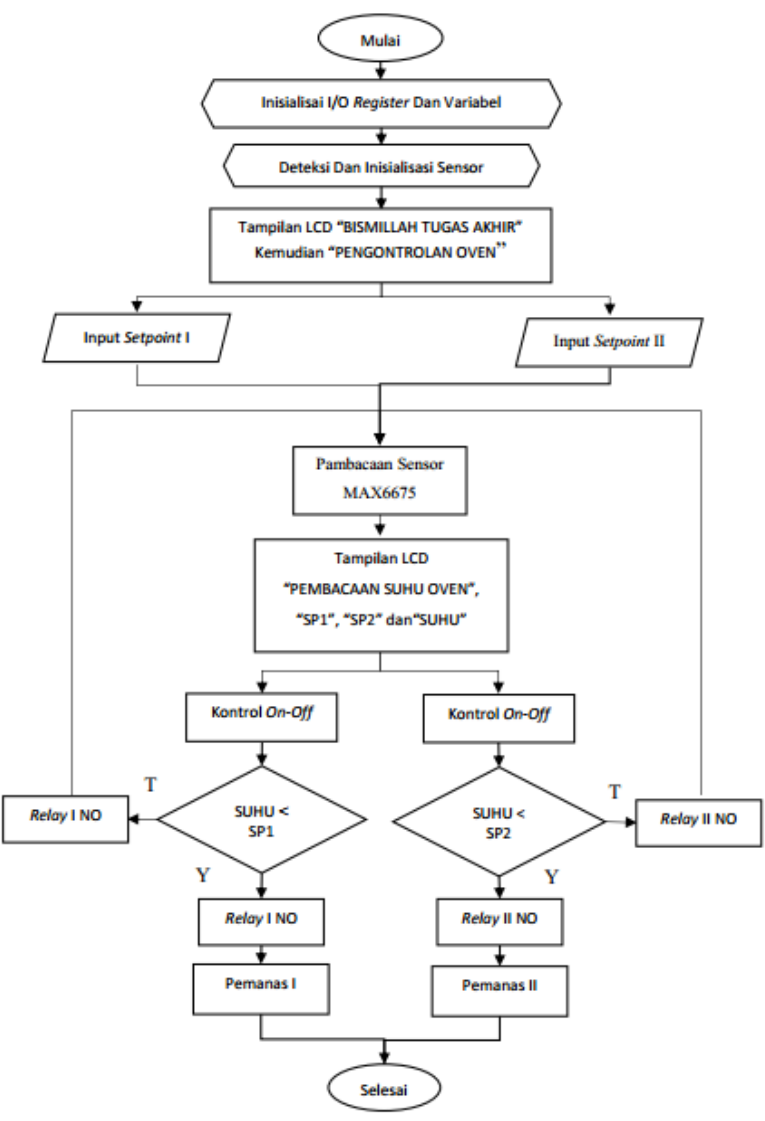

Gambar 2. Diagram Alir Oven

\subsubsection{Perancangan Kontrol $\mathrm{ON}-\mathrm{OFF}$}

Dalam sistem kendali on-off, sistem mempunyai dua keadaan yaitu on dan off. Karena nya hasil pengendalian kendali on-off akan menyebabkan process variable yang bergelombang [6]. Sinyal keluaran kontroler adalah u(t) dan sinyal pembangkit kesalahan (dead band) adalah e(t). Pada kendali on-off, sinyal u(t) akan tetap pada salah satu nilai maksimum atau minimum tergantung pada sinyal pembangkit kesalahan positif atau negatif sedemikian rupa sehingga:

$$
\begin{aligned}
& u(t)=u 1 \text { untuk } \mathrm{e}(\mathrm{t})>0 \\
& u(t)=u 2 \text { untuk } \mathrm{e}(\mathrm{t})<0
\end{aligned}
$$

$u 1$ dan $u 2$ adalah konstan. Harga minimum $u 2$ biasanya nol atau $-u 1[7]$.

Dalam beberapa hal dead band terjadi sebagai akibat adanya penghalang yang tidak diinginkan dan gerakan yang hilang, namu sering juga hal ini dimaksudkan untuk mencegah operasi yang berulangulang dari mekanisme onoff [8]. Gambar 3. menunjukkan kurva suhu (t) terhadap waktu (t) sistem kendali on-off.

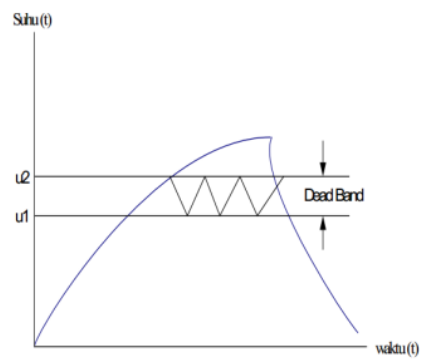

Gambar 3. Kurva suhu (t) terhadap Waktu (t) Sistem Kendali on-off

Pada Penelitian ini menggunakan kerja kendali on-off dengan memanfaatkan adjustable dead band yang ada pada temperature switch dan pressure switch. Nilai setpoint ditentukan pada suhu tertentu kemudian dilakukan kendali on-off sehingga membuat nilai setpoint berada diantara nilai u1 dan $\mathrm{u} 2$. Suhu akan berada didalam dead band karena ketika suhu melewati setpoint maka relay akan $O N$ dan mematikan pemanas. Kondisi tersebut akan membuat suhu pada nilai u1. Selanjutnya ketika suhu dibawah setpoint maka relay akan $O F F$ dan pemanas akan kembali bekerja. Diagram blok sistem kendali on-off pada oven listrik ditunjukkan pada Gambar 4

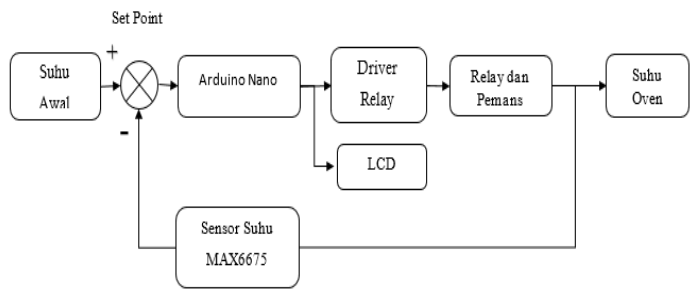

Gambar 4. Diagram Blok Sistem Kendali On-Off pada Oven Listrik

Pada perancangan Penelitian ini kendali on-off digunakan 
untuk mengatur suhu pada oven listrik sesuai dengan referensi yang diinginkan yaitu $40^{\circ} \mathrm{C}, 60^{\circ} \mathrm{C}$ dan $80^{\circ} \mathrm{C}$.

\section{Hasil dan Analisis \\ 3.1. Pengujian Perangkat Keras \\ 3.1.1. Pengujian Sensor MAX6675}

Pengujian sensor MAX6675 dilakukan dengan membandingkan suhu yang terbaca oleh sensor dengan suhu yang terbaca oleh termometer digital. Dari perbandingan tersebut didapat Hasil pengujian sensor suhu MAX6675 ditunjukkan oleh Tabel 1.

Tabel 1. Pengujian Sensor Suhu MAX6675

\begin{tabular}{cccc}
\hline No & $\begin{array}{c}\text { Sensor Suhu } \\
\text { MAX6675 } \\
\text { Pertama }\left({ }^{\circ} \mathrm{C}\right)\end{array}$ & $\begin{array}{c}\text { Suhu } \\
\text { Termometer } \\
\left({ }^{\circ} \mathrm{C}\right)\end{array}$ & |Error| $\left({ }^{\circ} \mathrm{C}\right)$ \\
\hline 1 & 26,39 & 26,3 & 0,09 \\
2 & 30,44 & 30,3 & 0,14 \\
3 & 39,03 & 38,9 & 0,13 \\
4 & 59.92 & 59.8 & 0.12 \\
5 & 76,37 & 76,2 & 0,17 \\
& \multicolumn{2}{|c}{$\mid$ Error| rata-rata } & 0,13 \\
\hline
\end{tabular}

Dari data pada Tabel 1. dapat dilihat bahwa dari lima kali pengambilan data antara pembacaan sensor MAX6675 dengan termometer digital didapatkan |Error| rata-rata sebesar $0,13^{\circ} \mathrm{C}$

\subsubsection{Pengujian Relay}

Program dari Arduino Nano yang diberikan pada driver relay kemudian di gunakan untuk mengaktifkan dan mematikan relay pada pemanas, berdasarkan nilai suhu yang terbaca oleh sensor MAX6675 jika nilai suhu nya dibawah batas atas setpoint maka relay akan tertutup (NC) dan pemanas akan hidup kemudian jika suhu nya lebih dari setpoint maka relay akan terbuka (NO) dan pemanas akan mati. Pada algoritma pemograman, kondisi relay akan hidup dalam kondisi LOW dan akan mati dalam kondisi HIGH. Pada kodisi LOW, LED warna hijau pada relay akan menyala dan menunjukkan relay sedang aktif. Gambar 5. menunjukkan pengujian relay pemanas.

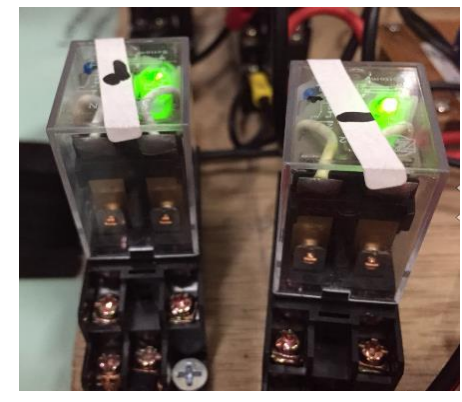

Gambar 5. Pengujian Relay Pemanas

\subsection{Pengujian Respon Sistem Kontrol On-Off}

Pengujian kontrol on-off dilakukan untuk mengetahui kemampuan dari kontrol on-off dalam mencapai setpoint suhu yang diinginkan. Pengujian kontrol on-off dapat dibagi menjadi sepuluh pengujian dengan variasi pemanas dan suhu

\subsubsection{Pengujian Respon Sistem Pada Pemanas Resistif Berbahan Kanthal pada Setpoint Suhu $40^{\circ} \mathrm{C}$}

Pengujian respon sistem pada setpoint suhu $40^{\circ} \mathrm{C}$ dilakukan dengan mengirimkan setpoint suhu $40^{\circ} \mathrm{C}$ melalui potensiometer I. Pengujian ini dilakukan pada kondisi suhu awal oven sebesar $26,43^{\circ} \mathrm{C}$.

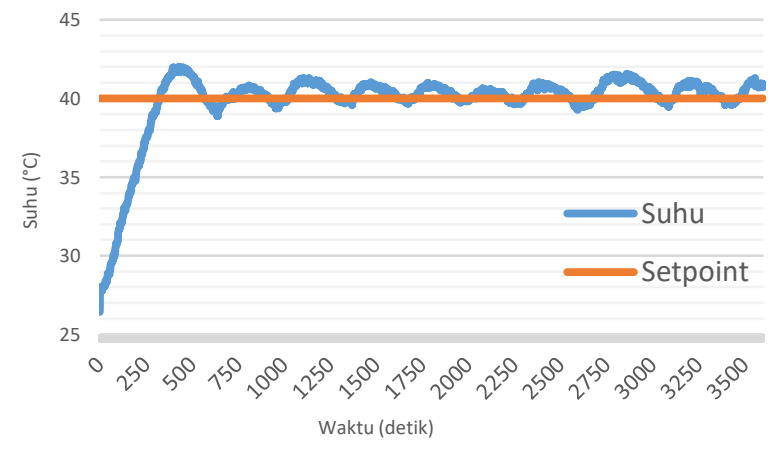

Gambar 6. Hasil Pengujian Respon Sistem Pada Pemanas Resistif Berbahan Kanthal pada Setpoint Suhu $40^{\circ} \mathrm{C}$

Gambar 6. menunjukkan hasil pengujian respon sistem pada pemanas resistif berbahan Kanthal pada setpoint suhu $40^{\circ} \mathrm{C}$. Berdasarkan hasil pengujian respon sistem dapat dilihat bahwa kontrol on-off mampu mencapai dan mempertahankan keluaran suhu sesuai dengan setpoint $40^{\circ} \mathrm{C}$ dengan tanggapan respon untuk waktu tunda (Td) sebesar 145 detik, waktu naik (Tr) sebesar 324 detik, waktu puncak (Tp) sebesar 438 detik, dan maximum overshoot (Mp) sebesar $4,95 \%\left(1,98^{\circ} \mathrm{C}\right)$.

\subsubsection{Pengujian Respon Sistem Pada Pemanas Resistif Berbahan Kanthal pada Setpoint Suhu $60^{\circ} \mathrm{C}$}

Pengujian respon sistem pada setpoint suhu $60^{\circ} \mathrm{C}$ dilakukan dengan mengirimkan setpoint suhu $60^{\circ} \mathrm{C}$ melalui potensiometer I. Pengujian ini dilakukan pada kondisi suhu awal oven sebesar $26,42^{\circ} \mathrm{C}$.

Gambar 7. menunjukkan hasil pengujian respon sistem pada pemanas resistif berbahan Kanthal pada setpoint suhu $60^{\circ} \mathrm{C}$. Berdasarkan hasil pengujian respon sistem dapat dilihat bahwa kontrol on-off mampu mencapai dan mempertahankan keluaran suhu sesuai dengan setpoint $60^{\circ} \mathrm{C}$ dengan tanggapan respon untuk waktu tunda (Td) sebesar 434 detik, waktu naik (Tr) sebesar 1208 detik, waktu puncak (Tp) sebesar 1365 detik, dan maximum overshoot $(\mathrm{Mp})$ sebesar $2,15 \%\left(1,29^{\circ} \mathrm{C}\right)$. 


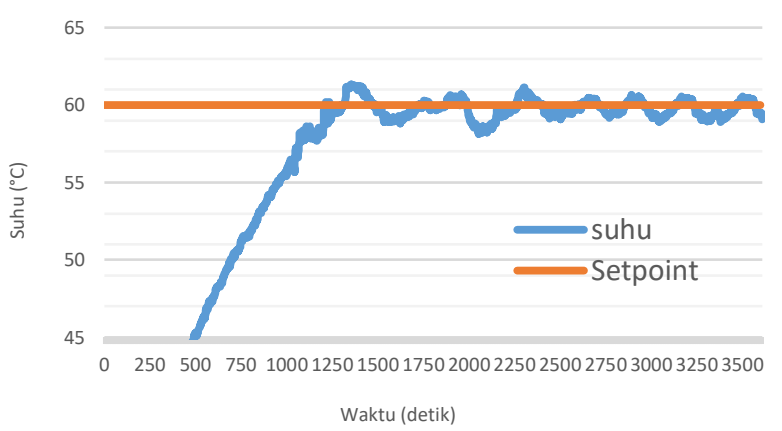

Gambar 7. Hasil Pengujian Respon Sistem Pada Pemanas Resistif Berbahan Kanthal pada Setpoint Suhu $60^{\circ} \mathrm{C}$

\subsubsection{Pengujian Respon Sistem Pada Pemanas Resistif Berbahan Nichrome pada Setpoint Suhu $40^{\circ} \mathrm{C}$}

Pengujian respon sistem pada setpoint suhu $40^{\circ} \mathrm{C}$ dilakukan dengan mengirimkan setpoint suhu $40^{\circ} \mathrm{C}$ melalui potensiometer I. Pengujian ini dilakukan pada kondisi suhu awal oven sebesar $26,4^{\circ} \mathrm{C}$.

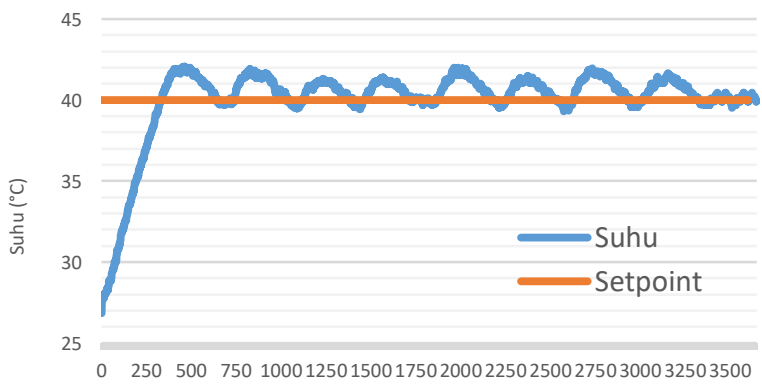

Waktu (detik)

Gambar 8. Hasil Pengujian Respon Sistem Pada Pemanas Resistif Berbahan Nichrome pada Setpoint Suhu $40^{\circ} \mathrm{C}$

Gambar 8. menunjukkan hasil pengujian respon sistem pada pemanas resistif berbahan Nichrome pada setpoint suhu $40^{\circ} \mathrm{C}$ Berdasarkan hasil pengujian respon sistem dapat dilihat bahwa kontrol on-off mampu mencapai dan mempertahankan keluaran suhu sesuai dengan setpoint $40^{\circ} \mathrm{C}$ dengan tanggapan respon untuk waktu tunda (Td) sebesar 149 detik, waktu naik (Tr) sebesar 331 detik, waktu puncak (Tp) sebesar 458 detik, dan maximum overshoot (Mp) $4,975 \%\left(1,99^{\circ} \mathrm{C}\right)$.

\subsubsection{Pengujian Respon Sistem Pada Pemanas Resistif Berbahan Nichrome pada Setpoint Suhu $60^{\circ} \mathrm{C}$}

Pengujian respon sistem pada setpoint suhu $60^{\circ} \mathrm{C}$ dilakukan dengan mengirimkan setpoint suhu $60^{\circ} \mathrm{C}$ melalui potensiometer I. Pengujian ini dilakukan pada kondisi suhu awal oven sebesar $26.8^{\circ} \mathrm{C}$.

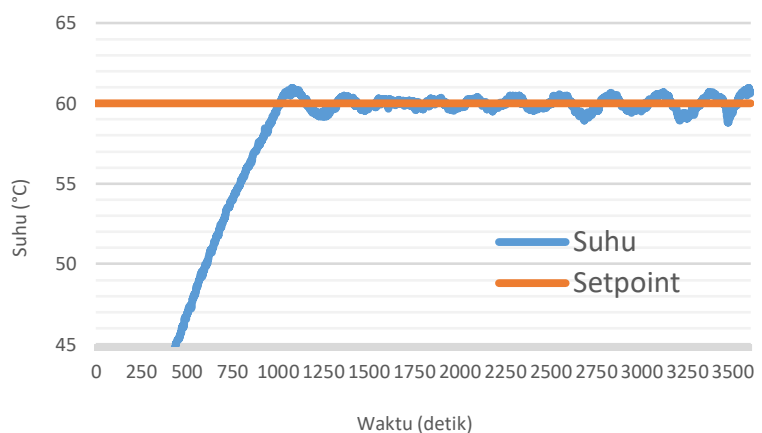

Gambar 9. Hasil Pengujian Respon Sistem Pada Pemanas Resistif Berbahan Nichrome pada Setpoint Suhu $6^{\circ} \mathrm{C}$

Pada Gambar 9. menunjukkan hasil pengujian respon sistem pada pemanas resistif berbahan Nichrome pada setpoint suhu $60^{\circ} \mathrm{C}$. Berdasarkan hasil pengujian respon sistem dapat dilihat bahwa kontrol on-off mampu mencapai dan mempertahankan keluaran suhu sesuai dengan setpoint $60^{\circ} \mathrm{C}$ dengan tanggapan respon untuk waktu tunda (Td) sebesar 398 detik, waktu naik (Tr) sebesar 1009 detik, waktu puncak (Tp) sebesar 1082 detik, dan maximum overshoot $(\mathrm{Mp})$ sebesar $1,6 \%\left(0,96^{\circ} \mathrm{C}\right)$.

\subsubsection{Pengujian Respon Sistem Pada Pemanas Induksi pada Setpoint Suhu $40^{\circ} \mathrm{C}$}

Pengujian respon sistem pada setpoint suhu $40^{\circ} \mathrm{C}$ dilakukan dengan mengirimkan setpoint suhu $40^{\circ} \mathrm{C}$ melalui potensiometer II. Pengujian ini dilakukan pada kondisi suhu awal oven sebesar $26,37^{\circ} \mathrm{C}$.

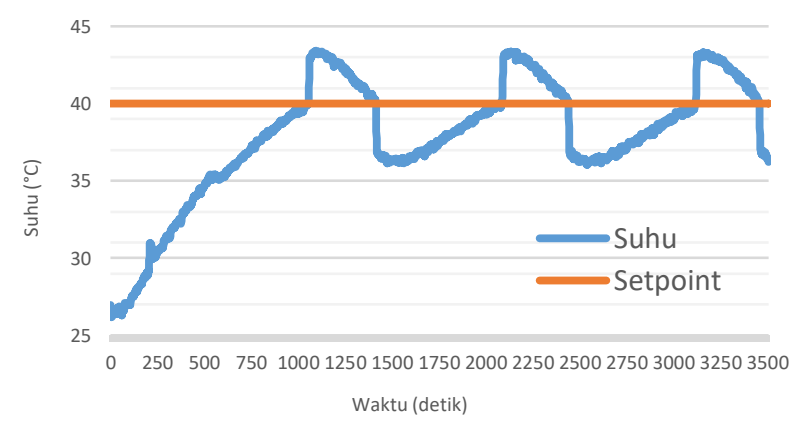

Gambar 10. Hasil Pengujian Respon Sistem Pada Pemanas Induksi pada Setpoint Suhu $40^{\circ} \mathrm{C}$

Gambar 10. menunjukkan hasil pengujian respon sistem pada pemanas induksi pada setpoint suhu $40^{\circ} \mathrm{C}$. Berdasarkan hasil pengujian respon sistem dapat dilihat bahwa kontrol on-off dengan setpoint $40^{\circ} \mathrm{C}$ memiliki tanggapan respon untuk waktu tunda (Td) sebesar 403 detik, waktu naik (Tr) sebesar 1049 detik, waktu puncak (Tp) sebesar 1094 detik, dan maximum overshoot (Mp) sebesar $8,55 \%\left(3,42^{\circ} \mathrm{C}\right)$. 


\subsubsection{Pengujian Respon Sistem Pada Pemanas Gabungan Pemanas Resistif Berbahan Nichrome dengan Pemanas Induksi pada pada Setpoint Suhu $60^{\circ} \mathrm{C}$}

Pengujian respon sistem pada setpoint suhu $60^{\circ} \mathrm{C}$ dilakukan dengan mengirimkan setpoint suhu $60^{\circ} \mathrm{C}$ melalui potensiometer I dan II . Pengujian ini dilakukan pada kondisi suhu awal oven sebesar $26,54^{\circ} \mathrm{C}$.

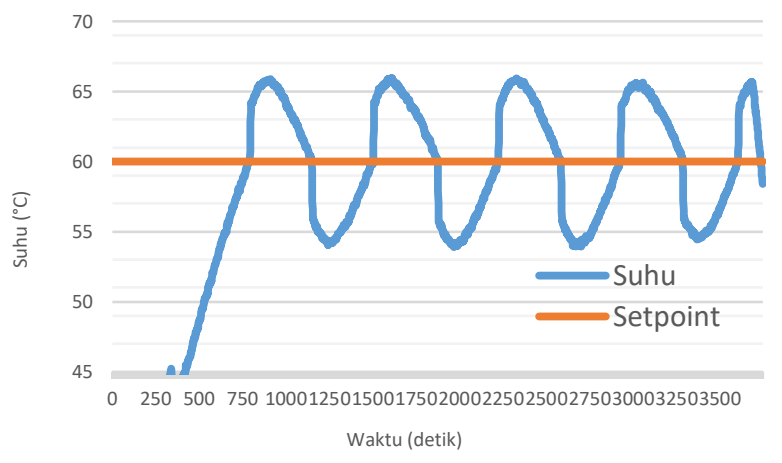

Gambar 11. Hasil Pengujian Respon Sistem Pada Pemanas Gabungan Pemanas Resistif Berbahan Nichrome Dengan Pemanas Induksi Pada Setpoint Suhu $60^{\circ} \mathrm{C}$

Pada Gambar 11. menunjukkan hasil pengujian respon sistem pada pemanas gabungan pemanas resistif berbahan nichrome dengan pemanas induksi pada setpoint suhu $60^{\circ} \mathrm{C}$. Berdasarkan hasil pengujian respon dapat dilihat bahwa kontrol on-off dengan setpoint $60^{\circ} \mathrm{C}$ memiliki tanggapan respon untuk waktu tunda (Td) sebesar 374 detik, waktu naik (Tr) sebesar 780 detik, waktu puncak (Tp) sebesar 904 detik, dan maximum overshoot (Mp) sebesar $9,7 \%\left(5,82^{\circ} \mathrm{C}\right)$.

\subsubsection{Pengujian Respon Sistem Pada Pemanas Gabungan Pemanas Resistif Berbahan Nichrome dengan Pemanas Induksi pada pada Setpoint Suhu $80^{\circ} \mathrm{C}$}

Pengujian respon sistem pada setpoint suhu $80^{\circ} \mathrm{C}$ dilakukan dengan mengirimkan setpoint suhu $80^{\circ} \mathrm{C}$ melalui potensiometer I dan II. Pengujian ini dilakukan pada kondisi suhu awal oven sebesar $26,12^{\circ} \mathrm{C}$.

Gambar 12. menunjukkan hasil pengujian respon sistem pada pemanas gabungan pemanas resistif berbahan nichrome dengan pemanas induksi pada setpoint suhu $80^{\circ} \mathrm{C}$. Berdasarkan hasil pengujian respon dapat dilihat tanggapan respon untuk waktu tunda (Td) sebesar 471 detik, waktu naik (Tr) sebesar 1916 detik, waktu puncak (Tp) sebesar 1964 detik, dan maximum overshoot (Mp) sebesar $4,68 \%\left(3,74^{\circ} \mathrm{C}\right)$.

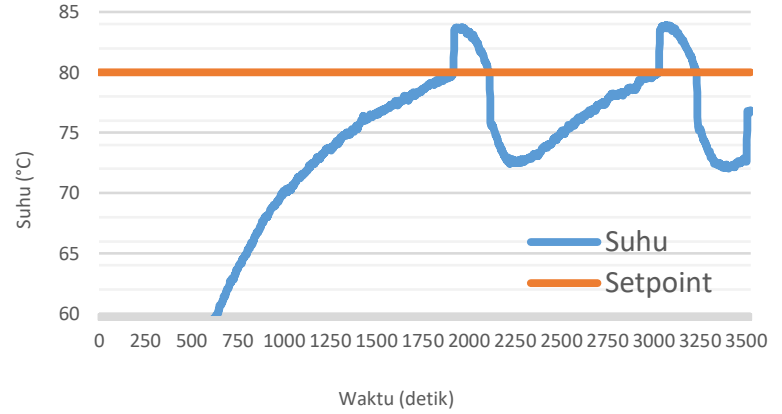

Gambar 12. Hasil Pengujian Respon Sistem Pada Pemanas Gabungan Pemanas Resistif Berbahan Nichrome Dengan Pemanas Induksi Pada Setpoint Suhu $80^{\circ} \mathrm{C}$

3.2.8. Pengujian Respon Sistem Pada Pemanas Gabungan Pemanas Resistif Berbahan Kanthal dengan Pemanas Induksi pada pada Setpoint Suhu $60^{\circ} \mathrm{C}$

Pengujian respon sistem pada setpoint suhu $60^{\circ} \mathrm{C}$ dilakukan dengan mengirimkan setpoint suhu $60^{\circ} \mathrm{C}$ melalui potensiometer I dan II . Pengujian ini dilakukan pada kondisi suhu awal oven sebesar $25^{\circ} \mathrm{C}$.

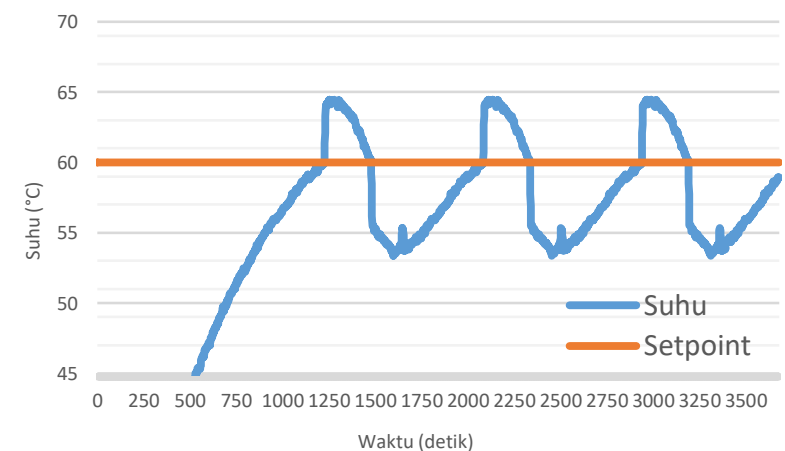

Gambar 13. Hasil Pengujian Respon Sistem Pada Pemanas Gabungan Pemanas Resistif Berbahan Kanthal dengan Pemanas Induksi Pada Setpoint Suhu $60^{\circ} \mathrm{C}$

Gambar 13. menunjukkan hasil pengujian respon sistem pada pemanas gabungan pemanas resistif berbahan kanthal dengan pemanas induksi pada setpoint suhu $60^{\circ} \mathrm{C}$. Berdasarkan hasil pengujian respon sistem dapat dilihat bahwa kontrol on-off dengan setpoint $60^{\circ} \mathrm{C}$ memiliki tanggapan respon untuk waktu tunda (Td) sebesar 470 detik, waktu naik (Tr) sebesar 1227 detik, waktu puncak (Tp) sebesar 1269 detik, dan maximum overshoot (Mp) sebesar 7,36\% $\left(4,42{ }^{\circ} \mathrm{C}\right)$.

Dari hasil pengujian respon sistem dengan variasi pemanas induksi dapat dilihat bahwa kontrol on-off bekerja dengan kurang baik dalam melakukan kontrol pada oven karena masih terjadi osilasi yang cukup besar. Osilasi tersebut 
dikarenakan sensor MAX6675 yang terhubung oleh thermocouple terganggu pembacaanya. Gangguan tersebut disebabkan oleh induksi dari inverter berfrekuensi tinggi yang memberikan panas terhadap logam yang bersifat feromagnetik. Thermocouple tipe- $\mathrm{K}$ sendiri terbuat dari bahan nikel dan kromium pada sisi positif sedangkan sisi negatif negatif terdiri dari nikel dan alumunium. Kromium yang memiliki sifat feromagnetik terpengaruh sehingga memiliki panas sendiri. Thermocouple menggunakan efek Seebeck pada prinsip kerjanya dimana arus yang sangat kecil akan mengalir melalui dua junction yang memiliki perbedaan temperatur. Ketika salah satu junction dapat menghasilkan panas sendiri maka arus yang mengalir dan tegangan yang keluar akan berbeda sehingga mengganggu pembacaan perbandingan tegangan oleh MAX6675 yang menyebabkan pembacaan suhu menjadi tidak akurat.

\section{Kesimpulan}

Berdasarkan pengujian dan analisis yang dilakukan pada perancangan pengontrolan suhu oven listrik menggunakan metode kontrol on-off. Diperoleh hasil pengujian sensor suhu didapatkan error rata-rata sebesar $0,13^{\circ} \mathrm{C}$. Pada pengujian relay didapatkan driver relay telah sesuai dengan program yang diberikan. Pada pengujian pemanas resistif berbahan kanthal dan nichrome system kendali on-off telah bekerja dengan baik dan memiliki nilai deadband yang rendah. Sedangkan pada hasil pengujian respon sistem dengan variasi pemanas induksi dapat dilihat bahwa kontrol on-off bekerja dengan kurang baik dalam melakukan kontrol pada oven karena masih terjadi osilasi yang cukup besar yang disebabkan oleh induksi dari inverter berfrekuensi tinggi.

\section{Referensi}

[1]. A. Nurhidayat, T. Mesin, U. Surakarta, K. Surakarta, and J. Barat, "Rekayasa Alat Pengering Untuk Meningkatan Produktivitas Ukm Emping Mlinjo," Semin. Nas. Sains dan Teknol., pp. 37-41, 2010.

[2]. A. S. I. Akbar, "Rancang Bangun Prototype Sistem Pemanggang Kue ( Oven ) Otomatis Dengan Menggunakan Mikrokontroler Avr Atmega 8535," Dielektrika, vol. 1, no. 2, pp. 69-81, 2014.

[3]. M. Imam, "Pengantar Sistem Kendali Otomatis," Depdikbud, Jakarta, 1995.

[4]. Adityo Pranowo, Wisnu Hendradjit, dan Sutanto Hadisupadmo, "Perancangan Sistem Kontrol Unit Water Chiller Laboratorium Teknik Kondisi Lingkungan," Oto.Ktrl.Inst (J.Auto.Ctrl.Inst) Vol 7 (1), 2015.

[5]. Yohandri Syufrawardi, Dan Asrizal, "Sistem Pengontrolan Temperatur On-Off Mikrokontroler At89c51 Dengan Pengindra Termokopel," AINSTEK Vol. XI, Nomor 1 September 2008.

[6]. Katsuhiko Ogata, "Modern Control Engineering fifth edition," Prentice Hall Inc, 2010.

[7]. Krista Tarigan, "Sistem Kontrol Teori contoh dan Analisis," 2009.

[8]. Wisnu Wulur, Muchlas, Nuryono Satya Widodo, "Karakteristik Sistem Kendali On-Off Suhu Cairan Berbasis Mikrokontroler AT90S8535" Penelitian. 